\title{
Kepatuhan Konsumsi Tablet Fe Metode MMAS-8 Mempengaruhi Kejadian Anemia Ibu Hamil di Puskesmas Glugur Darat tahun 2018
}

\author{
Clara Vanesia Bangun ${ }^{1}$, Harry Christama Simanjuntak ${ }^{2}$, Ronald Tambunan ${ }^{3}$, \\ Endy Juli Anto ${ }^{4}$ \\ ${ }^{1,2,3,4}$ Fakultas Kedokteran, Universitas Methodist Indonesia, Medan.
}

Info Artikel

Article history:

Diterima 19-06-2021

Revisi 29-06-2021

Disetujui 27-07-2021

\section{Kata kunci:}

Kepatuhan,

Tablet Fe,

Anemia,

Ibu Hamil.

\begin{abstract}
A B S T R A K
Data WHO menyebutkan bahwa $40 \%$ penyebab kematian ibu di negara berkembang berkaitan dengan anemia dalam kehamilan. Menurut data Riskesdas tahun 2013, prevalensi anemia pada ibu hamil di Indonesia sebesar $37 \%$, meningkat dari $24,5 \%$ di tahun 2007. Depkes RI membuat program pemberian tablet $\mathrm{Fe}$ melalui puskesmas dan posyandu. Salah satu kendala adalah rendahnya kepatuhan ibu hamil untuk mengkonsumsi tablet Fe. Tujuan penelitian ini adalah untuk mengetahui hubungan tingkat kepatuhan mengkonsumsi tablet Fe dengan metode MMAS-8 terhadap kejadian anemia pada ibu hamil di Puskesmas Glugur Darat tahun 2018. Penelitian cross sectional menggunakan metode analitik. Jumlah sampel 65 responden diambil dengan cara consecutive sampling, dilakukan di Puskesmas Glugur Darat Medan. Analisis data menggunakan uji Chi Square. Penderita anemia dalam kelompok umur tidak beresiko sebanyak 34 orang $(87,2 \%)$, primipara 15 orang $(38,5 \%)$, pendidikan menengah sebanyak 29 orang $(74,4 \%)$, tidak bekerja sebanyak 28 orang $(71,8 \%)$, tidak patuh mengkonsumsi tablet Fe sebanyak 29 orang $(74,4 \%)$. Analisis bivariat mendapatkan hubungan signifikan antara kepatuhan ibu hamil dalam mengkonsumsi tablet Fe dengan kejadian anemia $(\mathrm{p}=0,002)$. Terdapat hubungan antara tingkat kepatuhan mengkonsumsi tablet Fe dengan metode mmas- 8 terhadap kejadian anemia pada ibu hamil di Puskesmas Glugur Darat tahun 2018.
\end{abstract}

\author{
Koresponden Penulis: \\ Clara Vanesia Bangun, \\ Fakultas Kedokteran, Universitas Methodist Indonesia, Medan, \\ Jl. Hang Tuah No.8, Madras Hulu, Kec. Medan Polonia, Kota Medan, Sumatera Utara 20151. \\ Email: claravanesiabgn@gmail.com
}

\section{PENDAHULUAN}

Anemia merupakan kondisi jumlah dan ukuran sel darah merah atau konsentrasi hemoglobin di bawah nilai batas normal, akibatnya dapat mengganggu kapasitas darah untuk mengangkut oksigen ke seluruh tubuh. Anemia dalam kehamilan adalah kondisi ibu dengan kadar $\mathrm{Hb}$ di bawah $11 \mathrm{~g} \%$ pada trimester I dan III atau di bawah $10,5 \mathrm{~g} \%$ pada trimester II. 1

Dampak anemia pada kehamilan bervariasi dari keluhan sangat ringan hingga gangguan pada kehamilan meliputi abortus, partus immaturus atau persalinan prematur, gangguan proses persalinan meliputi inersia uteri, atonia uteri, partus lama, perdarahan dan pada masa nifas meliputi sub involusi uteri, infeksi, stress, kurangnya produksi Air Susu Ibu (ASI) dangan gangguan pada janin meliputi Berat Badan Lahir Rendah (BBLR), mikrosomia, kematian perinatal.2

Anemia dalam kehamilan merupakan masalah kesehatan yang utama di negara berkembang dengan tingkat kesakitan tinggi pada ibu hamil. Data World Health Organization (WHO) 2010 menyebutkan bahwa $40 \%$ penyebab kematian ibu di negara berkembang berkaitan dengan anemia dalam kehamilan. Menurut WHO, anemia mengenai sekitar 1,5 miliar orang didunia. Prevalensinya sangat tinggi di Afrika, Asia, India, Amerika Latin, Eropa Barat, dan Cina.3 Menurut data dan Riset 
Kesehatan Dasar (Riskesdas) tahun 2013, prevalensi anemia pada ibu hamil di Indonesia sebesar $37 \%$ meningkat dari tahun 2007 sebanyak $24,5 \% .4$

Sejak tahun 1975 Departemen Kesehatan Republik Indonesia (Depkes RI) membuat program pemberian tablet Fe melalui puskesmas dan posyandu. Akan tetapi banyak kendala yang menyertai program ini, salah satunya adalah rendahnya kepatuhan ibu hamil untuk mengkonsumsi tablet Fe.5

Faktor yang memengaruhi kepatuhan ibu hamil dalam mengonsumsi tablet Fe di antaranya ialah pengetahuan ibu hamil, motivasi ibu hamil, peranan keluarga, perilaku petugas kesehatan, efek samping obat. Pengetahuan pasien yang kurang terkait obat, meningkatkan risiko pasien untuk tidak patuh menjalankan terapinya.6 Menurut suatu kajian masalah anemia gizi dan program suplementasi pil zat besi pada ibu hamil, kepatuhan konsumsi tablet Fe juga dipengaruhi oleh rutinitas pasien/ibu kontrol ke posyandu/puskesmas. Faktor lain yang mempengaruhi kepatuhan adalah faktor lupa (forgetfulness). 7

Penelitian ini tentang hubungan kepatuhan mengkonsumsi tablet Fe dinilai dengan metode MMAS-8 terhadap kejadian anemia pada ibu hamil di Puskesmas Glugur Darat tahun 2018.

\section{METODE PENELITIAN}

Penelitian ini menggunakan metode analitik dengan pendekatan cross sectional. Penelitian ini untuk mengetahui hubungan tingkat kepatuhan mengkonsumsi tablet Fe dinilai dengan metode MMAS-8 terhadap kejadian anemia pada ibu hamil di Puskemas Glugur Darat tahun 2018. Pengamatan variabel-variabel hanya sesaat dan satu kali pengamatan selama penelitian.

\section{Kriteria Inklusi}

Ibu hamil trimester III yang datang memeriksakan kehamilannya, dan memperoleh tablet $\mathrm{Fe}$ dari petugas kesehatan yang bersedia ikut dalam penelitian.

\section{Kriteria Eksklusi}

Ibu hamil gemeli, ibu hamil yang memiliki riwayat perdarahan pada hamil saat ini, ibu hamil yang tidak bisa membaca dan menulis, ibu hamil yang menderita penyakit kronis.

\section{Variabel yang diteliti}

Variabel bebas (variabel independen) adalah Tingkat Kepatuhan Mengkonsumsi Tablet Fe dan Variabel terikat (variabel dependen) adalah Kejadian Anemia.

Pada penelitian ini data $\mathrm{Hb}$ pasien diperoleh dari hasil pemeriksaan menggunakan Easy Touch $G C H b^{\circledR}$ atau dari buku KIA. Penilaian tingkat kepatuhan mengkonsumsi tabet $\mathrm{Fe}$ menggunakan instrumen MMAS-8 (Lampiran). Data dianalisis dengan metode uji Chi Square.

\section{Tabel 1. Variabel Penelitian}

\begin{tabular}{|c|c|c|c|}
\hline Variabel & Definisi Operasional & Alat Ukur & Hasil Ukur \\
\hline Tingkat & Ketaatan ibu hamil dalam & Kuesioner & 1. Patuh : skor 6-8 \\
\hline Kepatuhan & $\begin{array}{l}\text { mengkonsumsi tablet Fe sesuai anjuran } \\
\text { petugas kesehatan yang diperoleh dari } \\
\text { ibu hamil trimester III yang sudah } \\
\text { mendapatkan tablet Fe pada kunjungan } \\
\text { pertama asuhan antenatal. }\end{array}$ & MMAS-8 & 2. Tidak Patuh : skor $<6$ \\
\hline Anemia & $\begin{array}{l}\text { Anemia merupakan suatu keadaan } \mathrm{Hb}< \\
11 \mathrm{~g} \% \text { pada trimester I dan III serta } \\
\text { kurang dari } 10,5 \mathrm{~g} \% \text { pada trimester II }\end{array}$ & $\begin{array}{l}\text { Easy } \\
\text { Touch }^{\circledR} \\
\text { GCHb } \\
\text { atau dari } \\
\text { buku KIA }\end{array}$ & $\begin{array}{ll}\text { 1. } & \text { Anemia : } \\
& \mathrm{Hb}<11 \mathrm{~g} \% \\
\text { 2. } & \text { Tidak Anemia }: \mathrm{Hb} \geq 11 \\
& \mathrm{~g} \%\end{array}$ \\
\hline Umur & $\begin{array}{l}\text { Usia ibu hamil saat pengumpulan data } \\
\text { yang dihitung sejak tanggal lahir ibu } \\
\text { sampai saat ulangtahun terakhir dalam } \\
\text { satuan tahun. }\end{array}$ & Kuesioner & $\begin{array}{ll}\text { 1. } & \text { Tidak berisiko }(23-35 \\
\text { thn }) \\
\text { 2. } \\
\text { Berisiko }(<23 \text { thn } \\
\text { dan }>35 \text { thn })\end{array}$ \\
\hline
\end{tabular}




\begin{tabular}{|c|c|c|c|}
\hline $\begin{array}{l}\text { Status } \\
\text { pekerjaan }\end{array}$ & $\begin{array}{l}\text { Kegiatan seseorang untuk mendapatkan } \\
\text { penghasilan }\end{array}$ & Kuesioner & 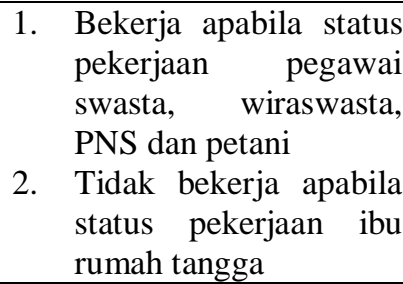 \\
\hline $\begin{array}{l}\text { Tingkat } \\
\text { pendidikan }\end{array}$ & $\begin{array}{l}\text { Tingkat pendidikan adalah tahapan } \\
\text { pendidikan yang ditetapkan berdasarkan } \\
\text { tingkat perkembangan peserta didik, } \\
\text { tujuan yang akan dicapai dan kemauan } \\
\text { yang dikembangkan }\end{array}$ & Kuesioner & $\begin{array}{l}\text { Dasar apabila tamat } \\
\text { SD/SMP sederajat } \\
\text { 2. Menengah apabila } \\
\text { tamat SMA/sederajat } \\
\text { 3. Tinggi apabila tamat } \\
\text { perguruan tinggi } \\
\text { sederajat }\end{array}$ \\
\hline $\begin{array}{l}\text { Jumlah } \\
\text { paritas }\end{array}$ & $\begin{array}{l}\text { Jumlah persalinan yang dialami ibu baik } \\
\text { anak yang melahirkan hidup atau } \\
\text { meninggal. Didapatkan dari anamnesis } \\
\text { pada kunjungan pertama pelayanan } \\
\text { antenatal dan buku KIA. }\end{array}$ & Kuesioner & $\begin{array}{ll}\text { 1. } & \text { Nullipara: belum } \\
& \text { pernah melahirkan } \\
\text { 2. Primipara: pernah } & \text { melahirkan 1 kali } \\
\text { 3. } & \text { Multipara: pernah } \\
\text { melahirkan 2-4 kali } \\
\text { 4. Grande multipara: } \\
\text { pernah melahirkan } \\
\text { lebih dari 5 kali. }\end{array}$ \\
\hline
\end{tabular}

\section{HASIL DAN PEMBAHASAN}

Data penelitian ini diambil dari 65 responden yang memenuhi kriteria inklusi dan eksklusi.

Tabel 1. Distribusi Frekuensi Kejadian Anemia Pada Ibu Hamil di Puskesmas Glugur Darat Tahun 2018

\begin{tabular}{lcc}
\hline \multicolumn{1}{c}{ Hb (hemoglobin) } & Frekuensi (n) & Persentase (\%) \\
\hline Tidak anemia (Hb 11 g\%) & 26 & 40 \\
Anemia $(\mathrm{Hb}<11 \mathrm{~g} \%)$ & 39 & 60 \\
\hline Total & 65 & 100
\end{tabular}

Ibu yang tidak anemia sebanyak 26 orang (40\%) sedangkan yang anemia sebanyak 39 orang (60\%)

Tabel 2. Distribusi Frekuensi Karakteristik Ibu Hamil Penderita Anemia Di Puskemas Glugur Darat Tahun 2018

\begin{tabular}{|c|c|c|c|}
\hline & Karakteristik & Jumlah (n) & Persentase (\%) \\
\hline \multicolumn{4}{|c|}{ Umur } \\
\hline - & Tidak Berisiko & 34 & 87,2 \\
\hline - & Berisiko & 5 & 18,8 \\
\hline \multicolumn{4}{|c|}{ Paritas } \\
\hline & Nullipara & 13 & 33,3 \\
\hline & Primipara & 15 & 38,5 \\
\hline & Multipara & 11 & 28,2 \\
\hline \multicolumn{4}{|c|}{ Tingkat Pendidikan } \\
\hline - & Rendah & 4 & 10,2 \\
\hline - & Menengah & 29 & 74,4 \\
\hline - & Tinggi & 6 & 15,4 \\
\hline \multicolumn{4}{|c|}{ Status Pekerjaan } \\
\hline- & Bekerja & 11 & 28,2 \\
\hline - & Tidak bekerja & 28 & 71,8 \\
\hline
\end{tabular}

Dari 39 ibu hamil penderita anemia mayoritas tidak berisiko sebanyak 34 orang $(87,2 \%)$, jumlah paritas primipara sebanyak 15 orang $(38,5 \%)$, pendidikan menengah sebanyak 29 orang $(74,4 \%)$, dan tidak bekerja sebanyak 28 orang $(71,8 \%)$. 
Tabel 3. Distribusi Frekuensi Ibu Hamil Penderita Anemia Bersdasarkan Tingkat Kepatuhan Mengkonsumsi Tablet Fe di Puskesmas Glugur Darat Tahun 2018

\begin{tabular}{lll}
\hline Hb (hemoglobin) & Frekuensi (n) & Persentase (\%) \\
\hline Tidak anemia (Hb 11 g\%) & 26 & 40 \\
\hline Anemia (Hb $<11 \mathrm{~g} \%)$ & 39 & 60 \\
\hline Total & 65 & 100 \\
\hline
\end{tabular}

Dari 39 ibu hamil penderita anemia, 10 orang $(25,6 \%)$ patuh mengkonsumsi tablet Fe dan 29 orang $(74,4 \%)$ tidak patuh mengkonsumsi tablet Fe (Tabel 3).

Tabel 4. Hubungan Kepatuhan Mengkonsumsi Tablet Fe dengan Metode MMAS-8 Terhadap Kejadian Anemia pada Ibu Hamil di Puskesmas Glugur Darat Tahun 2018.

\begin{tabular}{|c|c|c|c|c|c|c|c|}
\hline \multicolumn{8}{|c|}{ Kejadian Anemia } \\
\hline \multirow[t]{2}{*}{ Tingkat kepatuhan } & \multicolumn{2}{|c|}{ Anemia } & \multicolumn{2}{|c|}{ Tidak Anemia } & \multicolumn{2}{|c|}{ Total } & p-value \\
\hline & $\mathrm{f}$ & $\%$ & $\mathrm{f}$ & $\%$ & f & $\%$ & \\
\hline Patuh & 10 & 37 & 17 & 63 & 27 & 100 & 0,002 \\
\hline Tidak Patuh & 29 & 76,3 & 9 & 23,7 & 38 & 100 & \\
\hline Total & 39 & 60 & 26 & 40 & 65 & 100 & \\
\hline
\end{tabular}

Ibu hamil yang patuh mengkonsumsi tablet Fe, menderita anemia sebanyak 10 orang (37\%), yang tidak anemia sebanyak 17 orang ( 63\%); di antara ibu yang tidak patuh mengkonsumsi tabet Fe, menderita anemia sebanyak 29 orang $(76,3 \%)$ sedangkan tidak menderita anemia sebanyak 9 orang $(23,7 \%)$. Analisis data menyimpulkan bahwa terdapat hubungan antara tingkat kepatuhan mengkonsumsi tablet Fe dengan metode MMAS-8 terhadap kejadian anemia pada ibu hamil ( $\mathrm{p}=$ $0.002<0,05)$.

\section{Pembahasan}

Dari 65 responden di Puskesmas Glugur Darat tahun 2018, lebih banyak yang anemia yaitu 39 orang $(60 \%)$. Faktor risiko anemia adalah rendahnya asupan zat besi, absorpsi zat besi rendah, yang dapat disebabkan oleh konsumsi makanan mengandung fitat dan fenol. Selain itu, anemia juga disebabkan oleh kurang energi kronis (KEK), sosial ekonomi, paritas, status gizi, tingkat pengetahuan dan tingkat kepatuhan mengonsumsi tablet Fe oleh ibu hamil. ${ }^{7}$

Pada penelitian ini didapatkan responden yang menderita anemia lebih banyak dibandingkan yang tidak anemia. Hal ini mungkin dapat disebabkan oleh faktor-faktor risiko yang dapat dijumpai pada karakteristik responden, seperti mayoritas ibu hamil penderita anemia tidak bekerja yaitu $(71,8 \%)$ dan tingkat pendidikan menengah $(74,4 \%)$ (Tabel 2).

Dari 39 ibu hamil penderita anemia mayoritas yaitu 34 orang $(87,2 \%)$ berada dalam kelompok umur tidak berisiko (Tabel 2). Hasil penelitian ini tidak sesuai dengan teori faktor umur ibu terhadap kejadian anemia; namun jika umur ibu dihubungkan dengan status pekerjaan, didapatkan 34 orang ibu hamil penderita anemia pada kelompok umur tidak berisiko mayoritas tidak bekerja yaitu 24 orang $(70,6 \%)$ (Amartami, 2017). Berdasarkan penelitian lain hubungan pekerjaan dan status gizi ibu hamil memiliki hubungan yang signifikan secara statistik $(\mathrm{p}<0,05)$ terhadap kejadian anemia. ${ }^{8}$

Berdasarkan paritas, penelitian ini mendapatkan mayoritas ibu hamil penderita anemia adalah primipara yaitu sebanyak 15 orang $(38,5 \%$ ) (Tabel 2). Menurut teori bahwa anemia dipengaruhi kehamilan, makin sering hamil akan makin banyak cadangan zat besinya terkuras, serta organ reproduksi belum kembali sempurna. ${ }^{9}{ }^{10}$ Penelitian lain juga menyebutkan bahwa abortus akan menyebabkan ibu kehilangan banyak darah, sehingga proporsi anemia lebih besar pada ibu yang mempunyai riwayat abortus. ${ }^{11}$

Rendahnya tingkat pendidikan erat kaitannya dengan kurangnya akses informasi tentang anemia dan penanggulangannya, kurang memahami akibat anemia, kurang dapat memilih bahan makanan bergizi khususnya yang mengandung zat besi dan juga tingkat pengetahuan tentang tablet Fe serta kesadarannya terhadap konsumsi tablet Fe rendah sehingga berdampak pada terjadinya defisiensi besi. ${ }^{12}$ Hasil penelitian dari 39 ibu hamil yang anemia, mayoritas memiliki tingkat pendidikan menengah yaitu 29 orang $(74,4 \%)$ (Tabel 2). Sesuai teori bahwa pengetahuan seseorang dilatarbelakangi oleh pendidikan, apabila ibu hamil tingkat pendidikannya rendah maka akan sulit baginya menerima informasi, sehingga pengetahuannya tentang anemia dan faktor yang mempengaruhinya kurang yang kemudian akan berpengaruh terhadap konsumsi makanan yang mengandung zat besi sehingga ibu mengalami anemia. Selain itu, tingkat pengetahuan juga 
dipengaruhi oleh sumber informasi dan apabila pengetahuannya cukup mengenai anemia dalam kehamilan maka akan memotivasi ibu untuk mencegah terjadinya anemia, salah satunya dengan cara patuh mengkonsumsi tablet Fe. ${ }^{12}$

Hasil penelitian ini mendapatkan ibu hamil penderita anemia mayoritas tidak bekerja, yaitu 28 orang $(71,8 \%$ ) (Tabel 2). Ibu hamil yang tidak bekerja cenderung memiliki status sosial ekonomi lebih rendah karena sebagian besar pendapatannya bergantung pada penghasilan suami untuk memenuhi kebutuhannya. Pendapatan merupakan faktor yang paling menentukan kuantitas dan kualitas makanan dan gizi ibu saat hamil. Ibu yang tidak bekerja, kebutuhan nutrisinya tidak tercukupi saat hamil, sehingga berisiko mengalami anemia. ${ }^{10}$

Pada penelitian ini didapatkan 29 orang $(74,4 \%)$ ibu hamil tidak patuh mengonkonsumsi tablet Fe (Tabel 3). Menurut suatu kajian masalah anemia gizi dan program suplementasi pil zat besi pada ibu hamil, kepatuhan konsumsi tablet $\mathrm{Fe}$ dipengaruhi oleh rutin/tidak rutin ibu kontrol ke puskesmas. Faktor lain yang mempengaruhi kepatuhan adalah motivasi untuk mengkonsumsi tablet $\mathrm{Fe}$, faktor lupa (forgetfulness) untuk mengkonsumsinya dan juga efek samping setelah konsumsi. ${ }^{7}$ Penelitian Ramawati tahun 2012 di Desa Sokaraja mendapatkan bahwa tingkat pengetahuan sangat penting peranannya dalam menentukan kepatuhan konsumsi tablet Fe; pengetahuan ibu yang baik tentang manfaat tablet $\mathrm{Fe}$ akan memotivasi ibu untuk patuh mengkonsumsi tablet Fe. ${ }^{11,12}$ Rendahnya tingkat pendidikan ibu akan menyulitkan menerima informasi manfaat konsumsi tablet Fe selama kehamilan. ${ }^{12,13}$ Pada responden yang patuh tetapi mengalami anemia, hal ini karena faktor lain yang dapat mempengaruhi kadar $\mathrm{Hb}$ ibu hamil selain kepatuhan mengkonsumsi tablet Fe. Faktor-faktor lain yang mempengaruhi terjadinya anemia pada ibu hamil yaitu jarak kehamilan, penyakit kronis, kecukupan konsumsi zat gizi, dan malabsorbsi. ${ }^{14}$

Hasil penelitian ini mendapatkan hubungan signifikan antara tingkat kepatuhan konsumsi tablet Fe dinilai dengan metode MMAS-8 terhadap kejadian anemia pada ibu hamil $(\mathrm{p}=0,002)$ (Tabel 4). Kebutuhan zat besi pada wanita meningkat saat hamil dan melahirkan. Ketika hamil, seorang ibu tidak saja dituntut memenuhi kebutuhan zat besi untuk dirinya, tetapi juga harus memenuhi kebutuhan zat besi untuk pertumbuhan janinnya. Karena alasan tersebut, setiap ibu hamil disarankan mengonsumsi tablet Fe. ${ }^{15}$ Hasil kajian WHO (2012) menyebutkan bahwa ibu hamil yang mendapatkan suplementasi zat besi memiliki kadar hemoglobin lebih tinggi dibandingkan yang tidak. Kepatuhan minum tablet Fe memberi keuntungan bagi ibu hamil, sehingga penambahan zat besi secara teratur sangat diperlukan, untuk mencegah hal-hal tidak diinginkan. ${ }^{16}$

\section{KESIMPULAN}

Terdapat hubungan antara tingkat kepatuhan mengkonsumsi tablet Fe dinilai dengan metode MMAS-8 terhadap kejadian anemia pada ibu hamil di Puskesmas Glugur Darat tahun 2018.

\section{REFERENSI}

Sugiarsih U, Wariyah. Hubungan Tingkat Sosial Ekonomi Dengan Kadar Haemoglobin. (2013)Vol 4 no 2 h: 73-79. Available from: https://media.neliti.com/medi/publicati ons/106657-ID-hubungan-tingkatsosial-ekonomi-dengan-k.pdf.

Longgupa, Lisda Widianti. (2017). Hubungan Kepatuhan Mengkonsumsi Tablet Zat Besi (Fe) Dengan Peningkatan Kadar Hemoglobin (Hb) Pada Ibu Hamil di Puskesmas Donggala. Vol 4 no 2. Available from: http://ppjp.unlam.ac.id/journal/index.php/ JPKMI/ article /view/3427.

Api O, Breyman C, Cetiner M, Demir C, Ecder T. (2015). Diagnosis and Treatment of Iron Deficiency Anemia During Pregnancy and The Postpartum Period: Iron Deficiency Anemia Working Group Concens Report. Available from: https://www. ncbi.nlm.nih.gov/pmc/articles/PMC5558393/. Diakses pada 13 januari 2018.

Purwaningtyas ML, Prameswari GN. (2017). Faktor Kejadian Anemia Pada Ibu Hamil. HIGEIA 1(3). Available from: https://journal.unnes.ac.id/sju/index.php/higeia/article/ view/14291/8445. Diakses pada 12 Desember 2017.

Triyani S, Purbowati N. (2016). Kepatuhan Konsumsi Tablet Fe Dalam Mencegah Anemia Gizi Besi Pada Ibu Hamil Di Wilayah Puskesmas Kecamatan Jakarta Pusat. Vol 3 no 2. Available from: http://ejurnal.poltekkesjakarta3.ac.id/index.php/JITEK/ article/view/123/114. 
Adawiyani, R. (2013). Pengaruh Pemberian Booklet Anemia Terhadap Pengetahuan Kepatuhan Minum Tablet Tambah Darah Dan Kadar Hemoglobin Ibu Hamil. Vol 2 no 2. Available from: http://journal.ubaya.ac.id/index.php/jimus/article/view/725.

Aditianti, Permanasari Y, Julianti ED. (2015). Pendampingan Minum Tablet Tambah Darah (TTD) Dapat Meningkatkan Kepatuhan Konsumsi TTD Pada Ibu Hamil Anemia. Vol 38 no 1 h: 71-78. Available from: https://media.neliti.com/media/publica tions/223565-pendampingan-minumtablet-tambah-darah-t.pdf.

Ernawatik. Faktor-faktor yang Mempengaruhi Kejadian Anemia di Puskesmas Karangayar. Yogyakarta: Program Studi Bidan Pendidik Jenjang Diploma IV, Fakultas Ilmu Kesehatan Universitas Aisyiyah. 2017. Available from: http://digilib.unisayogya.ac.id/2704/1/naskah_publikasi.ernawatik_2017_07_24_04_01_07_273. pdf

Ramadani, M, Mayoritha, L \& Firiyani. 2012. Penyebab Kejadian Anemia Ibu Hamil Di Puskesmas Seberang Padang Kota Padang. Jurnal Kesehatan Masyarakat.Vol 6. No.2. Maret 2012. Available from: https://www.google.com/url?sa=t\&rct=j\&q=\&esrc=s\&source=web\&cd=2\&cad=rja\&uact=8\&ve $\mathrm{d}=2$ ahUKEwjE2sPok4viAhX46XMBHQlvB6EQFjABegQIARAC\&url=http\%3A\%2F\%2Fjurna 1.fkm.unand.ac.id\%2Findex.php\%2Fjkma\%2Farticle\%2Fview\%2F90\%2F96\&usg=AOvVaw0O F5fiNgj46APUfSSKBVw6

Rizkah Z, MT. (2017). Hubungan Antara Umur, Gravida, Dan Status Bekerja Terhadap Resiko Kurang Energi Kronis (KEK) Dan Anemia Pada Ibu Hamil. Vol 1 No 2. Available from: https://ejournal.unair.ac.id/AMNT/article/download/6228/3848.

Prawirohardjo. 2002. Ilmu kebidanan. Jakarta : FKUI.

Ramawati, D., Mursiyam, Sejati W. 2008. Faktor-faktor yang Mempengaruhi Kepatuhan Ibu Hamil Dalam Mengkonsumsi Tablet Besi di Desa Sokaraja Tengah Kec. Sokaraja Kab. Banyumas. Jurnal Keperawatan Soedirman Vol. 3 No. 1, Maret, 2008. Available from: http://jks.fikes.unsoed.ac.id/index.php/jks/article/view/158/73

Elisabeth, Lalita. 2013. Asuhan Kebidanan kehamilan. In Media

Silalahi, M. 2007. Analisis Faktor yang Berhubungan dengan Anemia Ibu Hamil di Kabupaten Dairi Tahun 2006 Available from: http://repository.usu.ac.id/bitstream/handle/123456789/6695/08E00070.pdf?sequence=1

Soebroto I. Cara Mudah Mengatasi Problem Anemia.Yogyakarta:Bangkit; 2009.

Yanti, Dhiny Easter. (2016). Hubungan Kepatuhan Konsumsi Tablet Fe Dengan Kejadian Anemia Pada Ibu Hamil Trimester III Di Puskesmas Bernung Kabupaten Pesawaran 2016. Vol 5 no 3. Available from: http://ejurnal.malahayai.ac.id/in dex.php?journal=jurdk\&page=article \&op=view \&path $\% 5 B \% 5 \mathrm{D}=342 \&$ path $\% 5 \mathrm{~B} \% 5 \mathrm{D}=302$. 